\title{
Community Knowledge in Restoring Trees in Controversial Forest Hot Spots: Case of Nkanya-Lusewa rivers catchment area in Zomba-Malosa Forest Reserve, Malawi
}

\author{
Gift G. Moyo ${ }^{1}$, Marlene Chikuni ${ }^{2}$, Sosten Chiotha ${ }^{2}$ \\ ${ }^{1}$ Malawi University of Science and Technology, Limbe, Malawi \\ ${ }^{2}$ University of Malawi, Limbe, Malawi
}

\section{OPEN ACCESS}

Citation: Moyo G. G., Chikuni M., Chiotha S. (2016) Community Knowledge in Restoring Trees in Controversial Forest Hot Spots: Case of Nkanya-Lusewa rivers catchment area in Zomba-Malosa Forest Reserve, Malawi. Open Science Journal 1(3)

Received: $18^{\text {th }}$ May 2016

Accepted: $21^{\text {st }}$ June 2016

Published: $5^{\text {th }}$ September 2016

Copyright: (C) 2016 This is an open access article under the terms of the Creative Commons

Attribution License, which permits unrestricted use, distribution, and reproduction in any medium, provided the original author and source are credited.

Funding: The author(s) received no specific funding for this work

\section{Competing Interests: The} author have declared that no competing interests exists.
*Corresponding author: Gift G. Moyo: gmoyo@must.ac.mw

\section{Abstract:}

Trees planted by the Forestry Department and other institutions in Nkanya-Lusewa river hotspot in Zomba-Malosa forest reserve in Domasi area in Malawi have not been surviving because villagers have been defiantly encroaching the forest reserve and this has led to many problems such as intermittent piped water supply in dry season. The study was done to investigate the community's knowledge on better forest restoration strategies in the hotspot and it involved 591 interviewees selected from 2,111 households in 25 villages. Several sampling methods were used such as cluster, purposeful, snowballing and accessibility methods. The majority of people in the area know the importance of forests and impacts of deforestation mostly citing direct-use values such as firewood, rainfall, construction materials, medicine, and water catchment conservation. Many villagers (56\%) view previous reforestation efforts in the area as being unsuccessful while $34 \%$ considered them as successful. Seedling uprooting, bush fires and lack of post-planting care are the key activities that lead to high mortality of young trees. Most respondents (28\%) indicated that yearly tree planting must fully involve the community and that garden owners must provide post-planting care (19\%) in their prohibited gardens. Khaya anthotheca, Senna siamea, Eucalyptus camaldulensis, Pterocarpus angolensis, Mangifera indica, Toona ciliata, Breonadia salicina, Uapaca kirkiana, and 
Albizia lebbeck were highly preferred for their various characteristics and purposes. Most villagers (96.1\%) are willing to participate in forestry activities as long as their views are appreciated while $3.4 \%$ of them indicated unwillingness because they are busy with personal work, are aged and/or sickly.

Keywords: Community Knowledge, Community Involvement, Forest Restoration

\section{Introduction}

Agroforestry and forest restoration ecology projects are established for different purposes such as conserving biodiversity, changing microclimate, improving groundwater recharge capacity, controlling soil erosion, provision of forest resource products, nutrients recycling, rehabilitating mines and other damaged ecosystems, and for boundary demarcation[1]. Authors have indicated the importance of being mindful of sustainable rural livelihoods and community participation in forest restoration programmes among other factors[2]. The fast growing and multipurpose trees such as Albizia lebbeck, Faidherbia albida, Acacia polyacantha, Gliricidia sepium, Moringa oleifera, Manihot glaziovii, Ziziphus mauritiana, Z. abyssinica, Senna siamea, Adansonia digitata, Z. mauritiana, Bridelia micrantha, and Cordyla africana are recommended for reforestation in many areas worldwide as well as in Malawi especially in a riparian system, in agroforestry programmes and for medication as they provide quick benefit to the ecosystem and humans [3][4]. F. albida, in particular provides fodder for wild and domestic animals, controls soil erosion, can be used as human food, and its bark can be used in treating toothache, diarrhea, bleeding, and inflamed eyes [5][6]. Studies have shown that integrating technical and indigenous knowledge systems to natural resources management is important as these have registered success in some areas such as in Amazon forest in Brazil, and Chibuwe forest reserve [7][8][9]. A number of authors and practitioners have also indicated the significance of stakeholders involvement for successful and sustainable natural resources management, conservation, and restoration projects [10][11][12][13][14].

Several projects have been implemented in the study area in collaboration with District Forest Office mostly using top-bottom approach but yielded insignificant fruits in terms of restoring trees. These include: the National Water Project (Management of water catchment areas) funded by the World Bank, and the European Union funded project called Improved Forest Management for Sustainable Livelihoods Programme (IFMSLP) in 2010 and 2012/13 respectively. They facilitated the formation of water catchment committees and development of hotspots plans, trained communities in various skills such as nursery production and tree caring, provided support for law enforcement, and planted trees within the catchment area. The IFMSLP, on the contrary, led to vibrant natural regeneration of trees in group village headman Mangumba in Minama 
Forest Management Block in 2007 which is just adjacent to Mtogolo Forest Management Block because the chief constantly encouraged the community to allow natural restoration of the bare hill to take place, plant trees in the backyards, and with strict simple village rules stopped illegal harvesting of trees in the village forest area [15]. The other project taking place in Zomba-Malosa Forest Reserve is Lake Chilwa Basin Climate Change Adaptation Programme (LBCCAP). This project has been conducting a number of activities such as training selected communities in various skills, conducting tree species diversity survey in three hotspots of Lake Chirwa basin (Malosa, Chikala hill and Michesi Forest Reserves), identified priority tree species for hotspots afforestation in the Lake Chirwa basin for 2010/11 plantation, and providing support for law enforcement and tree planting exercise in Forest Reserves, customary land and along some rivers [16][17]. The ten top priority species included Parkia filicoidea, Pericopss angolensis, Psidium guajava, Pterocarpus angolensis, Senna siamea, Syzygium cordatum, Terminalia sericea, Toona ciliata, Trichilia emetica, and Vitex payos. The study conducted however does not indicate the reasons given by the communities for preferring particular tree species and other forest restoration strategies.

A good forest canopy and resilient forest are of fundamental importance in maintaining water catchment but this is not the case with Nkanya and Lusewa rivers, which supply domestic water through Southern Region Water Board (SRWB) and Water User's Association (WUA) in Domasi area in Malawi. Since 2011, there have been observable effects of deforestation in Domasi area which include firewood scarcity and tap water shortage due to decline in water level in Nkanya and Lusewa. These result from extensive logging and subsequent invasion by farmers and charcoal burners in the marginal and fragile lands, and in the water catchment area of the forest reserve. The study was therefore carried out to investigate community's knowledge on the impact of deforestation in the area, reasons for past failures in reforestation programmes, and better strategies for restoring trees along Nkanya and Lusewa rivers.

\section{Study Area}

\section{Location and Demography}

Domasi, as a study area, is located in the northern part of Zomba city in Malawi, about $18 \mathrm{~km}$ from the city and about $20 \mathrm{~km}$ south of Machinga boma. It lies between latitude 15016' S and longitude 35030' E. According to Zomba District Assembly report [18], 70\% of the population in Zomba district falls below national poverty line making it one of the three poorest districts in Malawi, after Machinga $(73 \%)$ and Nsanje $(76 \%)$ as such the livelihood is pinned to natural resources such as trees. The majority of the population in the area are poor and the people's economic problems compel them to overexploit trees for firewood and charcoal as sources of energy and income resulting. The main research site falls under Mtogolo Local Forest Management Block which is part of Zomba-Malosa Forest Reserve. The Block is meant to protect and conserve natural resources in order to improve livelihoods of people found in Mtogolo group village, protect water catchment area by yearly planting trees, and enhance the availability of 
none-tree organisms and other forest products. The surrounding communities have been entrusted with the responsibility of looking after the resources found in the Forest Block and make use of them following laid down rules and regulations. Unfortunately, it has mainly been the 72 member forest block committee (2 members from each of the 36 surrounding villages) that proactively, under the supervision of Zomba district forestry office, takes part in forest conservation activities.

\section{Mtogolo Forest Block physiognomy}

The Forest Block is measured 2083 hectares and is divided into three major parts. Part 1, being the uppermost, is reserved for water catchment protection and as a source of rivers such as: Nkanya, Namichimba, Malosa, Lusewa, Mapalo, Chiwinja, Msambafisi, and Domasi rivers. Lusewa is a tributary of Nkanya river such that their co-joint is the water intake for Southern Region Water Board and Rural Water Supply. Part 2 of the Block, which is found just below Part 1, is reserved for natural tree regenerants such as Brachystegia bussei, Brachystegia boehmii, and Uapaca kirkiana. Part 3, which is found below Part 2, largely contains regenerants because big trees have been carelessly cut down by charcoal producers and farmers. The Block has been known to contain several plant species such as Khaya anthotheca, Pterocarpus angolenesis, Ficus sycomorus, Diplorhynchus condylocarpon, Ochna arborea, Brachystegia bussei, Uapaca kirkiana, Oncoba spinosa, Pseudolachnostylis maprouneifolia, Dalbergia melanoxylon, Brachystegia stipulata, Brachystegia spiciformis, Strychnos cocculoides, Erythrophleum guineense, Combretum apiculatum, and Toona ciliata with Brachystegia bussei, and Strychnos cocculoides by then being the common tree species. Unfortunately, most of these species have disappeared in the study area.

\section{Methodology}

\section{Research Design}

We used both probabilistic and non-probabilistic sampling methods in this study. Villages in this study acted as clusters. Households were selected using multistage sampling technique from which interviewees including a special group of people such as charcoal traders and those cultivating along the rivers under study were selected using simple random sampling, accessibility, purposeful and snowballing methods. The interview schedules guided by the questionnaires were used to solicit in-depth information from the sampled villagers on the community's livelihoods, knowledge on the importance and impact of deforestation in an area, tree species to be planted as well as better ways of restoring trees along Nkanya and Lusewa rivers.

\section{Sampling Sites and Size}

Village participants for interview schedule were sampled from 25 villages which are direct beneficiaries of natural resources from Mtogolo Forest Block and these villages are: Mtogolo, M'bwana, Galois, Malemia, Magwira 1, Magwira 2, Kalembo, Yoyola, Chiyesa, Nyamuka 1, Chilonga, Mpanje, Mtomoni, Sani, Saiti, 
Kili, Taulo, Mtaya, Likonde, Mkwela, Kwidjo, Msangeni, Mkomanje, and Manja. The Mtogolo group village as the main study area has 24 villages with a total human population size of 5,213 people while one village, Msangeni belongs to Mtwiche group village headman. The 25 villages under study had a population size of 6909 and 2,111 households as provided by chiefs (May, 2014) from which 591 households were randomly selected using same proportion. Then one person from each of the selected households was selected for in-depth interviews.

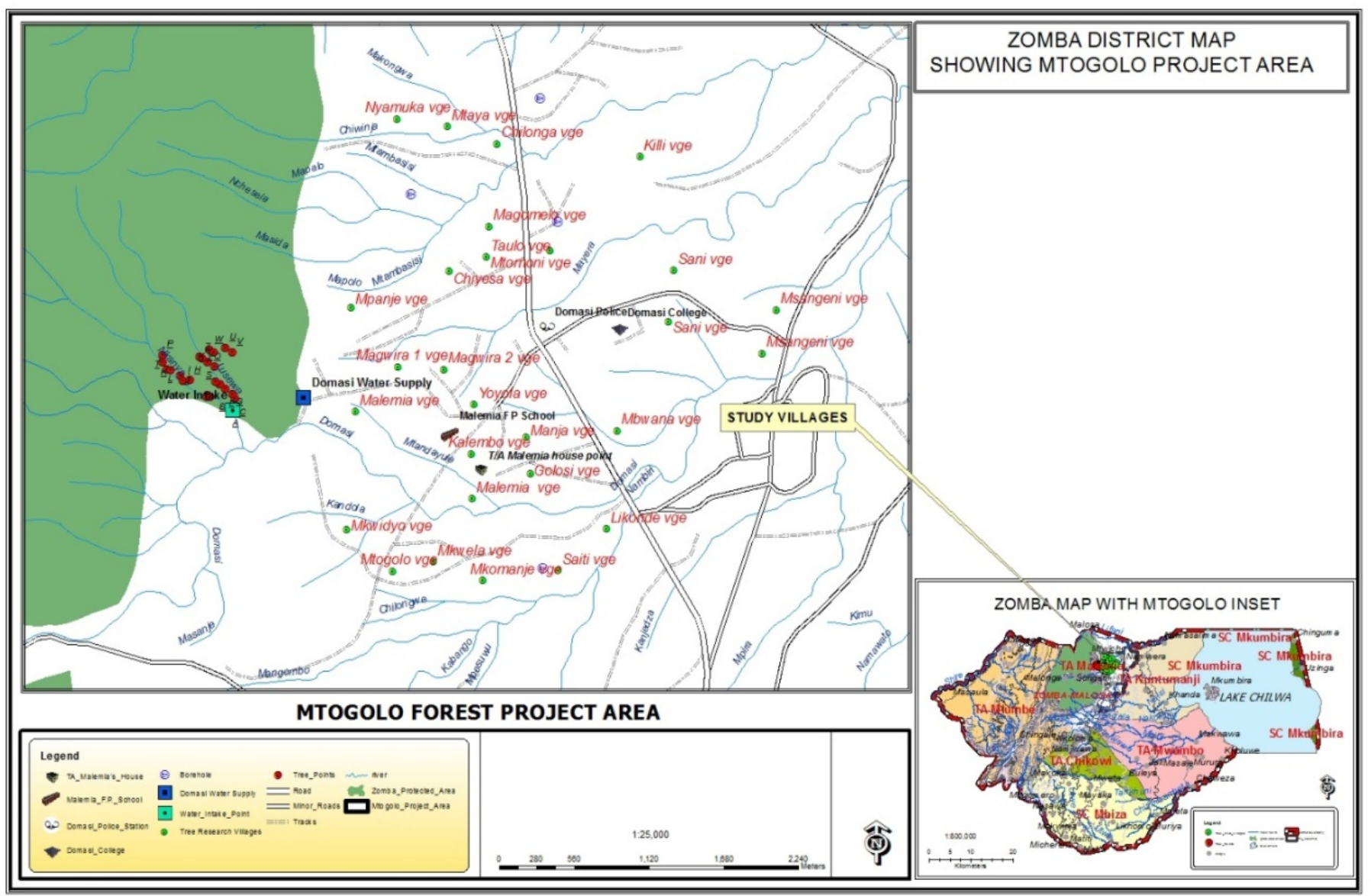

Figure 1: Map showing study Villages and Gardens in Mtogolo area in Domasi.

\section{Results and Discussion}

\section{Livelihood}

The success of any reforestation initiative largely depends on the livelihoods of the locals. Therefore the management and maintenance of forestry ecosystem is a function of the services and goods that it provides to human population for their livelihoods. On livelihood, we found that majority of the villagers chiefly rely on subsistence farming (95\% of respondents) while $5 \%$ compliment farming with other survival strategies such as business, house building piece work, carpentry, and permanent employment by the surrounding institutions. Most farmers $(72 \%)$ cultivate away from the forest reserve and these come from 
relatively distant villages (Table 1 ). However, $27 \%$ of the respondents indicated that they have encroached forest reserve for farming and mostly come from the villages bordering the reserve, namely Magwira 1, Magwira 2, Chiyesa, Nyamuka, Mpanje, Mtomoni, and Magomero. They have encroached the forest reserve due to the land shortage in the area and because of its high soil fertility, particularly in Nkanya-Lusewa river catchment. Malawi National Land Policy (2002) reveals this as a general problem in Malawi such that there is frequent and provocative squatting and encroachment in gazetted forests, national parks, on private land, and other protected areas in land pressure districts because the creation of these protected areas involved the displacement of the entire villages of which some were forced to move into valleys and uncultivable areas.

Table 1: Farming places for respondents.

\begin{tabular}{|l|c|c|c|c|}
\hline Farming places & Mountain & Domasi river & Nkanya river & Other places \\
\hline Respondents (\%) & 23 & 6 & 4 & 72 \\
\hline
\end{tabular}

\section{Knowledge on the importance of forest in Domasi area}

This study has revealed that most people in the area know the importance of the forest. Most of the respondents cited forest functionalities which are directly and immediately linked to them as opposed to indirect or secondary impacts or functions. The users appreciate and value natural resources such as forests in different ways which then signal variations in forest restoration, management, and conservation strategies to be adopted. Most respondents mentioned firewood provision as the major role of the forest reserve while run-off control and tourism were given the last positions because of their non-use value perceived by the community (Figure 2).

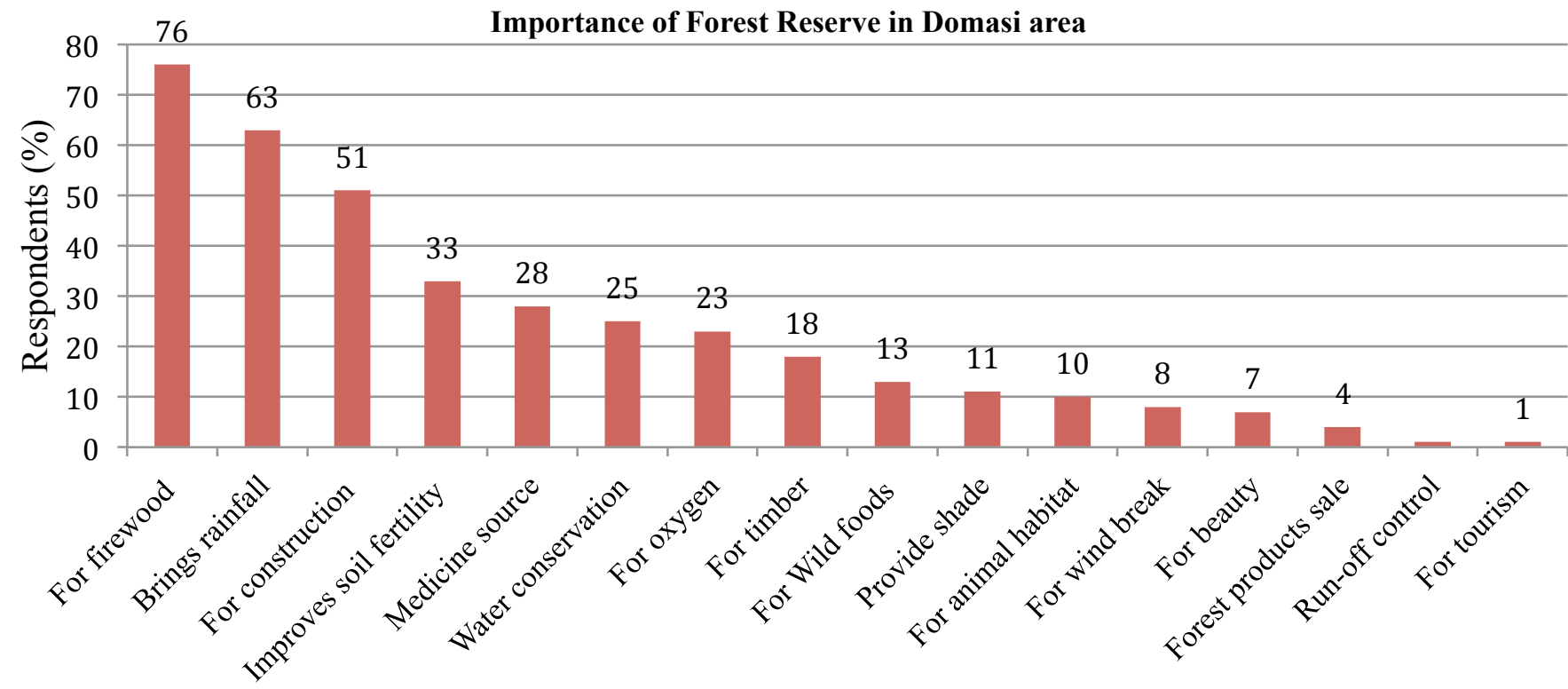

Forest importance

Figure 2: Graph showing importance of forest indicated by respondents. 


\section{Knowledge on the impact of deforestation in the area}

Ninety-seven percent of the respondents know various negative impacts brought by deforestation in the Domasi area and the majority cited erratic rainfall, firewood problem, soil erosion, drying up of rivers, and scarcity of wild animals (Figure 3). It is the high level of poverty and land scarcity that compel the villagers to continue overexploiting the forest resources through opening up of gardens, and collection of construction materials and firewood from regenerants. Promotion of alternative livelihood strategies and fuel sources such as bio pellets and woodlots are needed to save forest reserve trees. The shortage of rainfall has led to drying up of Nkanya and Lusewa rivers in dry season hence tap water problems in the area since 2011. Soil erosion and leaching due to uncontrolled run-off has resulted in the loss of soil fertility in the gardens such that farmers hardly harvest enough maize without applying fertilizer compared to the yield from the same piece of land in the past years when farmers were not applying fertilizer. Soil erosion has also resulted in siltation of Nkanya and Lusewa rivers leading to persistent blockage of water supply systems. A few respondents cited scarcity of wild animals and fruits, animal habitat shortage, herbs problem, shortage of timber, and blowing off of house roofs as some of the negative impacts of deforestation which was not the case before.

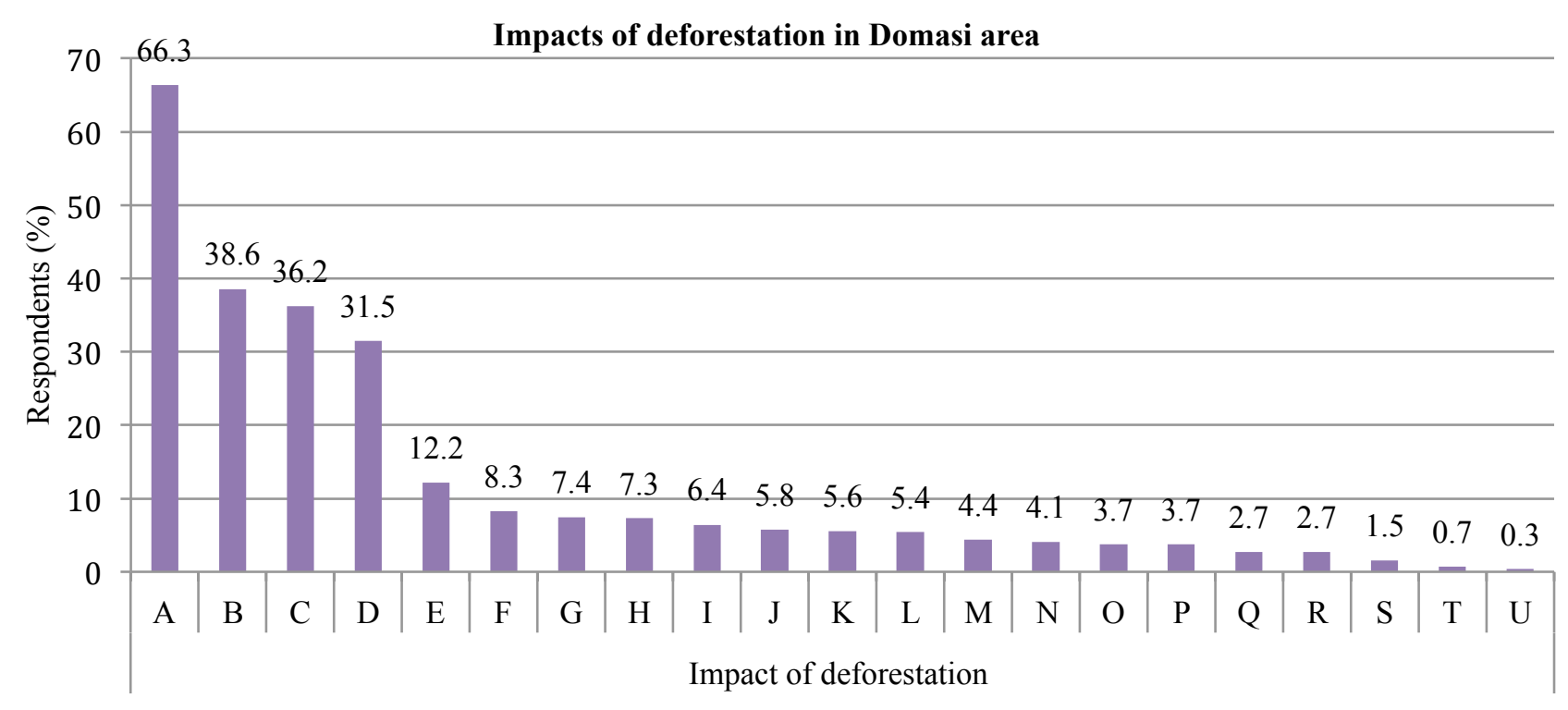

Figure 3: Graph showing impacts of deforestation in Domasi area.

KEY: $\boldsymbol{A}$ - Erratic rainfall, $\boldsymbol{B}$ - Wood fuel problem, $\boldsymbol{C}$ - Soil erosion, $\boldsymbol{D}$ - Drying up of rivers, $\boldsymbol{E}$ - Wild animals scarcity, $\boldsymbol{F}$ - Wild fruit scarcity, $\boldsymbol{G}$ - Animal habitat destruction, $\boldsymbol{H}$ - Herbs problem, $\boldsymbol{I}$ - No windbreaks, $\boldsymbol{J}$ - No runoff control, $\boldsymbol{K}$ - No fresh air, $\boldsymbol{L}$ - Invalid responses, $\boldsymbol{M}$ - Climate change, $\boldsymbol{N}$ - Construction material shortage, $\boldsymbol{O}$ Parasite incidence, $\boldsymbol{P}$ - Timber problem, $\boldsymbol{Q}$ - Bare grounds, $\boldsymbol{R}$ - Increased poverty, $\boldsymbol{S}$ - No shade, $\boldsymbol{T}$ - Fish shortage, $\boldsymbol{U}$ - Natural resources knowledge gap (children do not know plants previously available in the forest) 


\section{Knowledge on the success and failure of previous forest restoration efforts in the study area}

The study has revealed that most villagers (56\%) view the past forest restoration efforts by Zomba Forestry Department, SRWB and other programmes in the study site as being unsuccessful while $34 \%$ considered them as successful and $10 \%$ of them were not sure. The majority of respondents who alleged that the preceding programmes were successful inhabit distant villages from these rivers. These distant villages include: Mtogolo, Golosi, Malemia, Kalembo, Chiyesa, Saiti, Kili, Magomero, Chilonga, Msangeni, Mkwela, Mkomanje, and Manja. Nonetheless, the majority $(22 \%)$ of those who viewed the programmes as being successful failed to give reasons for the success but a few respondents (11\%) cited the yearly planting of trees despite the low survivorship. The other minor reasons given include: the perception that trees planted are sustainably utilized by the community (4\%), availability of post-planting care (weeding and the fire brakes) $(6 \%)$, and people are sternly warned against destroying trees (2\%). On the contrary, various reasons were given by those who indicated that the efforts have not been successful as indicated in Figure 4 below. The uprooting of seedlings and lack of post-planting care are the key activities that led to the low survival rate of planted trees because of the land wrangle existing between some villages and Forestry Department. Firstly, villagers who have encroached the reserve feared that the Forestry Department would grab their land that they were evacuated from to pave the way for forest reserve establishment if they let the planted trees grow. Another problem is that trees were being planted in the gardens of these forest encroachers without their involvement hence they saw no reason for providing post planting care to these trees because to them, trees belong to the government while the land belongs to them.

\section{Reasons for unsuccessful forest restoration effort (\%)}

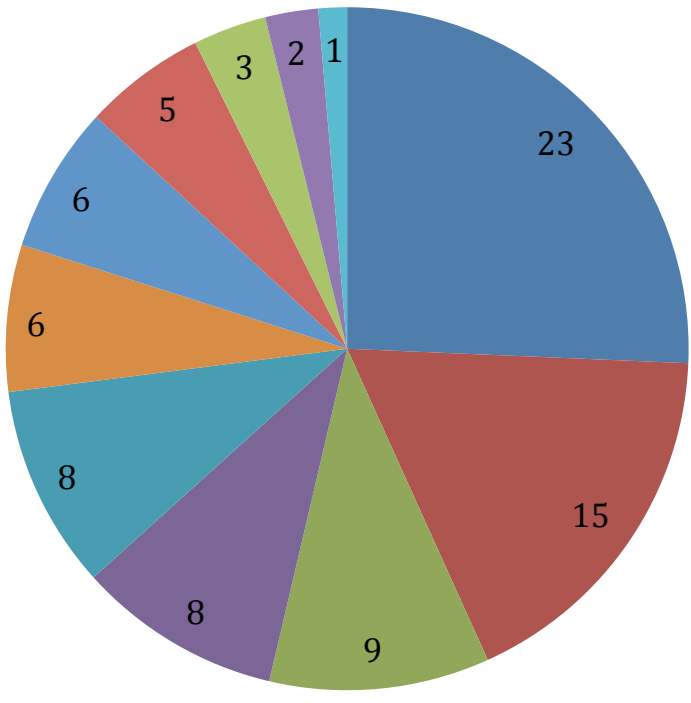

- Trees uprooted due to land wrangle anger

Wild bush fires

Cutting trees for no apparent reasons

- Seedlings not watered

- No post-planting weeding

Lack of forest patrol

- Poor villagers-forest officers relationship

No follow-up schedules

Late planting

- Inadequate tree care training

No incentives to communities

-

Figure 4: Pie chart showing reasons for past failures in forest restoration efforts. 


\section{Knowledge on better strategies for restoring trees along Nkanya and Lusewa rivers}

This study has revealed that the community knows a number of potential resource management practices and possible forest restoration strategies (Figure $5)$. Most respondents (28\%) pointed out that yearly planting of trees must continue in different places and that post-planting care must be done by the garden owners since the block committee members fail to take care of trees in these illegal gardens for fear of being harmed. There were variations in preference of strategies for restoring and managing forests among the villages although some methods were common to all.

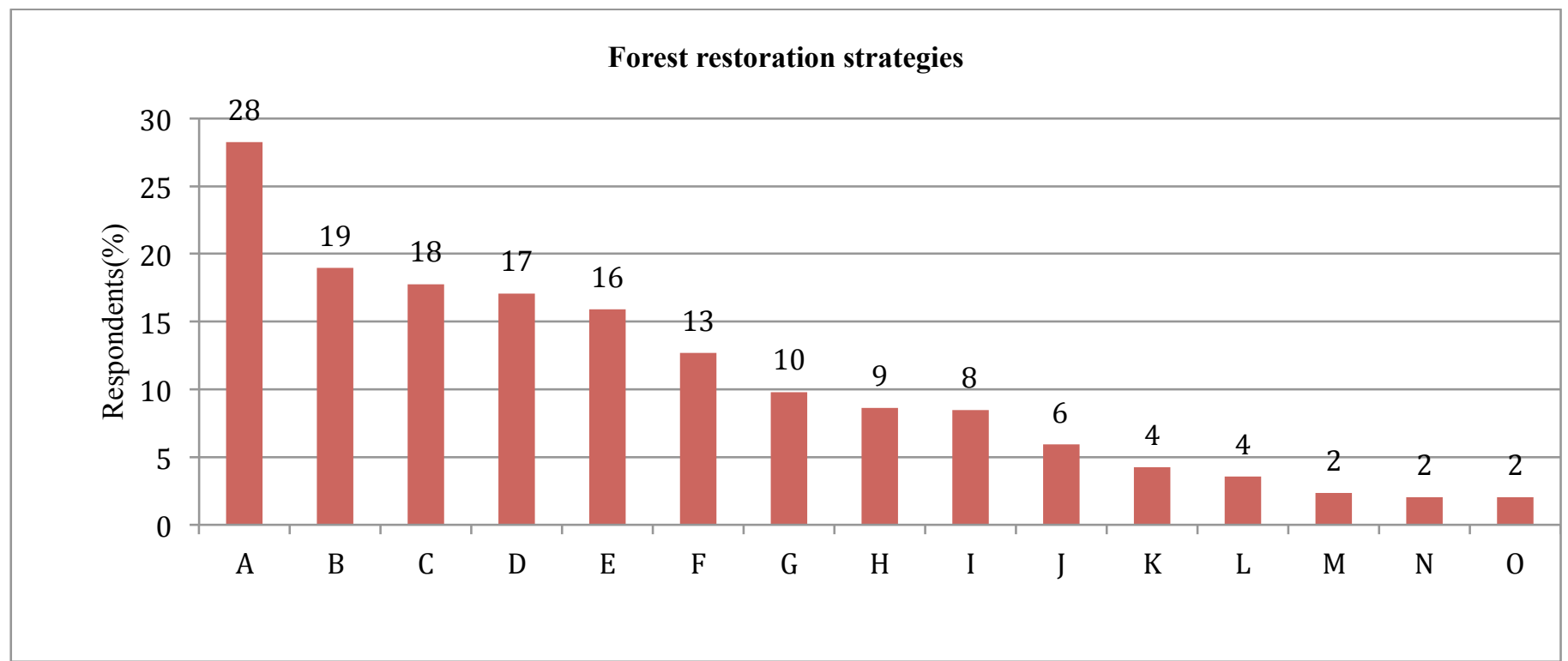

Figure 5: Graph showing suggested strategies for quick forest restoration in Domasi area.

KEY: $\boldsymbol{A}$ - Continue planting more trees (yearly), $\boldsymbol{B}$ - Regular post-planting weeding in the plantation, $\boldsymbol{C}$ - Villagers should be employed as forest guards, $\boldsymbol{D}$ - Have follow-up schedules after tree planting, $\boldsymbol{E}$ - Community should be civiceducated, $\boldsymbol{F}$ - Chiefs must be fully involved, $\boldsymbol{G}$ - Institute and implement strict forest rules, $\boldsymbol{H}$ - Practicing agroforestry, $\boldsymbol{I}$ - Proper tree harvesting and utilization, $\boldsymbol{J}$ - Cooperation between villagers and Forest officials, $\boldsymbol{K}$ Prepare firebreaks, $\boldsymbol{L}$ - Farmers must be responsible for tree caring in their gardens, $\boldsymbol{M}$ - Consulting farmers before tree planting in their gardens, $\boldsymbol{N}$ - Irrigating newly planted trees, $\boldsymbol{O}$ - Diversifying tree species

\section{Suggested tree species for quick tree restoration in Nkanya-Lusewa river catchment}

The local community has an idea on good tree species for the area and for various purposes as deduced from their tree preferences. They generally preferred indigenous and quick- growing exotic non-timber trees which have direct-use value to them though most of these trees are not native to these rivers. Most tree species are preferred because they: are fast growing, conserve water, improve soil fertility, are used for firewood, survive better in a dry season, for construction, and are easy to grow. Khaya anthotheca, Senna siamea, Eucalyptus camaldulensis, Pterocarpus angolensis, Mangifera indica, Toona ciliata, Breonadia salicina, Uapaca kirkiana, Albizia lebbeck, and Gmelina arborea were preferred for their different characteristics such as quick growth, easiness in planting and care, and timber and wood fuel production (Table 2). The Forestry 
Department and SRWB have been planting some of these trees in the same rivers but still very few have survived indicating that an unsuitable approach was being used for this community. It should be noted that some trees suggested by the community such as Eucalyptus and Gmelina are not ideal for riparian system indicating that some villagers do not know the negative ecological impacts that can be brought by these species.

Table 2: Preferred tree species for Nkanya and Lusewa rivers

\begin{tabular}{|c|c|}
\hline Tree species & Respondents on the species (\%) \\
\hline Khaya anthotheca & 82.6 \\
\hline Senna siamea & 32.8 \\
\hline Faidherbia albida & 22.0 \\
\hline Eucalyptus camaldulensis & 17.9 \\
\hline Pterocarpus angolensis & 13.4 \\
\hline Mangifera indica & 11.8 \\
\hline Toona ciliata & 10.8 \\
\hline Breonadia salicina & 8.6 \\
\hline Uapaca kirkiana & 6.6 \\
\hline Albizia lebbeck & 5.6 \\
\hline Gmelina arborea & 5.1 \\
\hline Terminalia sericea & 4.4 \\
\hline Pinus patula & 4.2 \\
\hline Afzelia quanzensis & 3.7 \\
\hline Adina microcephala & 2.9 \\
\hline Ficus sycomorus & 2.4 \\
\hline Widdringtonia whytei & 2.2 \\
\hline Acacia polyacantha & 1.5 \\
\hline Pericopsis angolensis & 1.4 \\
\hline Moringa oleifera & 1.4 \\
\hline Parkia filicoidea & 1.4 \\
\hline Melia azedarach & 1.2 \\
\hline Psidium guajava & 1.2 \\
\hline Pereia americana & 1.0 \\
\hline Erythrophleum guiieense & 1.0 \\
\hline Colophospermum mopane & 1.0 \\
\hline Bridelia micrantha & 1.0 \\
\hline
\end{tabular}

\section{Suggested tree species for planting in the Distant gardens and backyards}

The diversification of plants in backyards, orchards and woodlots also needs enhancement rather than concentrating only on forest reserves. In this study, Mangifera indica was mostly preferred for backyard gardens because of its multipurpose features such as the provision of firewood, food, medicine, and shade. Other highly preferred trees included Eucalyptus, S. siamea, and K.anthotheca since they are used for timber, shade and are continuously regenerating. The study has further established that people prefer tree species in their gardens and backyards that can provide immediate benefits, for instance, 
fruits (M.indica, P.americana, C.sinensis, P.guajava, U. kirkiana , C.papaya, C.limon, C.tangerina, P.persica, and A.senegalensis) and construction materials (Eucalyptus, S. siamea, G. arborea, and G. sepium).

Table 3: Preferred tree species for planting in the gardens and backyards.

\begin{tabular}{|c|c|}
\hline Tree species & Respondents on the species (\%) \\
\hline Mangifera indica & 52.1 \\
\hline Eucalyptus sp. & 36.4 \\
\hline Senna siamea & 31.1 \\
\hline Khaya anthotheca & 24.9 \\
\hline Persea americana & 23.2 \\
\hline Citrus $x$ sinensis & 17.1 \\
\hline Psidium guajava & 16.8 \\
\hline Faidherbia albida & 16.4 \\
\hline Uapaca kirkiana & 14.7 \\
\hline Carica papaya & 9.5 \\
\hline Citrus $x$ limon & 7.3 \\
\hline Moringa oleifera & 4.9 \\
\hline Gmelina arborea & 4.2 \\
\hline Citrus tangerine & 2.5 \\
\hline Prunus persica & 2.2 \\
\hline Melia azedarach & 2.0 \\
\hline Annona senegalensis & 2.0 \\
\hline Gliricidia sepium & 1.4 \\
\hline Widdringtonia whytei & 1.2 \\
\hline
\end{tabular}

\section{Willingness of the community to take part in forest restoration activities}

We have established that most villagers (96.1\%) are willing to participate in forestry activities as long as the implementers of the activities appreciate the views and wishes of the community. These people have valuable knowledge and skills which if harnessed there will be better forest restoration programmes implemented along the rivers under study and the entire area. Only $3.4 \%$ of respondents showed unwillingness because they are busy with personal work, are at old age, and sickness while $0.5 \%$ were undecided.

\section{Conclusion and Recommendation}

This study has found that the villagers have knowledge on the importance of forests in the area, effects of deforestation, reasons that led to the failure of previous forest programmes, better strategies for restoring the forest, and various tree species which can be planted along the rivers as well as house backyards based on different reasons. The study has also established problems that existed in forest co-management committees instituted by the Forestry Department and other projects in the area. The community has clearly shown its willingness to 
take part in forestry programmes because they have experienced the problems brought about by deforestation that they themselves have caused. However, they want to be fully involved from the onset of the programmes up to the end and to directly benefit from the programmes. Therefore it is recommended that the key community members, forest reserve bordering villagers, and persistent forest degraders should be fully involved prior to and during the entire forest restoration programmes.

\section{References:}

[1] Grathwohl,J. and Greenberg,R. (1988). Saving the tropical forest. London: Earthscan Publications Ltd.

[2] Chazdon, R.L.(2008). Beyond Deforestation: Restoring Forests and Ecosystem Services on Degraded Lands.Science. Vol. 320: 5882, pp 1458-1460.

[3] Meke, G. and Chirwa,P.W.(2004). The newsletter of Forestry Institute of Malawi. FRIM Newsletter. Issue No.91.

[4] Heuzé V. and Tran G. (2013). Apple-ring acacia (Faidherbia albida). Feedipedia.org. A programme by INRA, CIRAD, AFZ and FAO.

[5] Wentling,M.G.(1983).Acacia albida: Aboreal Keystone of Successful Agro-pastoral Systems in Sudano-Sahelian Africa. USAID.

[6] AGFAX (January, 2010). Plant your own Fertilizer Factory. http:www.agfax.net/transcript/agfax305.doc

[7] Tanyanyiwa, V.I. and Chikwanha M. (2011). The role of indigenous knowledge systems in the management of forest resources in Mugabe area, Masvingo Zimbabwe. Journal of Development in Africa.Vol.13:3

[8] Grenier, L. (1998). Working with Indigenous Knowledge: A Guide for Researchers. IDRC: Ottawa, Canada

[9] Mukwanda, G.(2000). Natural Resources Conservation and Management. Zimbabwe Open University, Harare.

[11] Nyberg ,B.(1999). An introductory guide to adaptive management for project leaders and participants. Canada: B.C. Forest Service

[12] Williams, B. (2011). Adaptive management of natural resources -framework and issues. Journal of Environmental Management. Vol. 92, pp 1346-1353.

[13] Stankey, G.H.,Clark, R.N.and Bormann, B.T.(2005). Adaptive management of natural resources: theory, concepts and management institutions. USA: Department of Agriculture, Forest Service.

[14] Della, D.A., Martin, A., Spivak,R., Schulke,T., Bird B. et al, (2003). A Citizen's Call for Ecological Forest Restoration: Forest Restoration Principles and Criteria. Ecological Restoration Vol. 21:1.

[15] Mangumba Village Forest Area. http.//www.ifmslp.org/mangumba.php (accessed on 9.8. 2013)

[16] FRIM (2004). Diversity survey in three hotspots of Lake Chirwa basin: Malosa, Chikala hill and Michesi forest reserves. Malawi: FRIM

[17] Likoswe M., Msukwa V., Namoto M., and MkwezalambaI.(2010). Priority tree species for hot spots afforestation in the Lake Chirwa basin for plantation in 2010/11. Malawi : FRIM

[18] Zomba District Assembly (2009). Zomba District Socio Economic Profile 2009-2012. Zomba: Zomba District Assembly. 